\title{
Infection and reinfection of Stomoxys calcitrans larvae (Diptera: Muscidae) by entomopathogenic nematodes in different times of exposure
}

\author{
Infecção e reinfecção de larvas de Stomoxys calcitrans (Diptera: Muscidae) por \\ nematoides entomopatogênicos em diferentes tempos de exposição
}

\begin{abstract}
Américo de Castro Monteiro Sobrinho1* (D); Isadora Luiza Alves Costa²; Graziele Calixto Souza1; Luís Carlos de Souza Rodrigues Leal'; joão Luiz Lopes Monteiro Neto ${ }^{3}$; Melissa Carvalho Machado do Couto Chambarelli4; Avelino José Bittencourt ${ }^{5}$
\end{abstract}

\begin{abstract}
${ }^{1}$ Programa de Pós-graduação em Ciências Veterinárias, Universidade Federal Rural do Rio de Janeiro - UFRRJ, Seropédica, RJ, Brasil ${ }^{2}$ Curso de Graduação em Medicina Veterinária, Universidade Federal Rural do Rio de Janeiro - UFRRJ, Seropédica, RJ, Brasil ${ }^{3}$ Departamento de Solos e Engenharia, Universidade Federal de Roraima - UFRR, Boa Vista, RR, Brasil

${ }_{4}^{4}$ Departamento de Parasitologia Animal, Instituto de Veterinária, Universidade Federal Rural do Rio de Janeiro - UFRRJ, Seropédica, RJ, Brasil

${ }^{5}$ Departamento de Medicina e Cirurgia Veterinária, Instituto de Veterinária, Universidade Federal Rural do Rio de Janeiro - UFRRJ
\end{abstract} Seropédica, RJ, Brasil

How to cite: Monteiro Sobrinho AC, Costa ILA, Souza GC, Leal LCSR, Monteiro Neto JLL, Chambarelli MCMC, et al. Infection and reinfection of Stomoxys calcitrans larvae (Diptera: Muscidae) by entomopathogenic nematodes in different times of exposure. Braz J Vet Parasitol 2021; 30(3): e003721. https://doi.org/10.1590/S1984-29612021069

\begin{abstract}
Stomoxys calcitrans is a hematophagous dipteran. Several agents are used in biological control, including entomopathogenic nematodes (EPNs). Bioassay I involved an evaluation of the effect of Heterorhabditis bacteriophora HP88 and Heterorhabditis baujardi LPP7 on S. calcitrans larvae in different periods of exposure. Groups of 10 larvae were placed in Petri dishes and 200 EPNs/larva were added, which were divided into groups according to the exposure times of 2, 4, 6, 12, 24 and 48 hours. The purpose of Bioassay II was to evaluate the efficacy of the EPNs in infecting S. calcitrans larvae when they were isolated from stable fly larvae in Bioassay I. Groups of 10 larvae were placed in Petri dishes and 200 EPNs/larva were added. In bioassay I, H. bacteriophora caused mortality rates of 51.7, 83.3 and $91.7 \%$ in 12,24 and 48 hours, respectively, while $H$. baujardi caused mortality rates of 9.3 (12h), 35 (24h) and 35\% (48h). In Bioassay II, H. bacteriophora and H. baujardi resulted in mortality rates of $35 \%$ and $25 \%$, respectively. It was concluded that the longest exposure times presented the highest larval mortality and that EPNs isolated from S. calcitrans are not efficient in controlling the larvae fly.
\end{abstract}

Keywords: Stable fly, Heterorhabditis, periods of exposure.

\begin{abstract}
Resumo
Stomoxys calcitrans é um díptero hematófago. Vários agentes são usados no controle biológico, incluindo nematoides entomopatogênicos (NEPs). O bioensaio I objetivou avaliar o efeito de Heterorhabditis bacteriophora HP88 e Heterorhabditis baujardi LPP7 sobre larvas de S. calcitrans em diferentes períodos de exposição. Grupos de 10 larvas foram colocados em placas de Petri, adicionou-se 200 NEPs/larva, e foram divididos de acordo com tempos de exposição de 2, 4, 6, 12, 24 e 48 horas. O objetivo do Bioensaio II foi avaliar a eficácia dos NEPs na infecção de larvas de S. calcitrans, quando esses foram isolados de larvas da mosca oriundos do Bioensaio I. Os grupos de 10 larvas foram colocados em placas de Petri e 200 NEPs/larva foram adicionados. No bioensaio I, $H$. bacteriophora causou taxas de mortalidade de 51,7\%, 83,3\% e 91,7\% em 12, 24 e 48 horas, respectivamente, enquanto $H$. baujardi causou taxas de mortalidade de 9,3\% (12h), 35\% (24h) e 35\% (48h). No Bioensaio II, H. bacteriophora e $H$. baujardi resultaram em taxas de mortalidade de $35 \%$ e $25 \%$, respectivamente.
\end{abstract}

Received March 8, 2021. Accepted July 14, 2021

*Corresponding author: Américo de Castro Monteiro Sobrinho. E-mail: am_ene@hotmail.com 
Concluiu-se que os maiores tempos de exposição apresentaram as maiores mortalidades larvais e que NEPs isolados de S. calcitrans não são eficientes no controle das larvas mosca.

Palavras-chave: Mosca dos estábulos, Heterorhabditis, períodos de exposição.

\section{Introduction}

Stomoxys calcitrans (Linnaeus, 1758) (Diptera: Muscidae) is a hematophagous dipteran commonly known as the stable fly, which can parasitize several animal species and may also affect humans. The duration of the life cycle of S. calcitrans depends directly on the environment and climate of the region (Bittencourt, 2012). Parasitism by this fly is detrimental to cattle in Brazil and around the world. The action of this fly causes annual economic losses estimated at 2.2 billion dollars in the United States (Taylor et al., 2012), and 335.5 million dollars in Brazil (Grisi et al., 2014). However, the latter figure does not take into account the impact of recent outbreaks reported in some regions of Brazil (Dominghetti et al., 2015).

Arthropod pests have become resistant to most chemical pesticides (Barros et al., 2019). In addition, society is becoming increasingly aware about the effects of these substances on nature and human health, so new means are needed to control these organisms. Biological control is an alternative method, which minimizes the accumulation of chemical residues in agricultural products and lowers pest resistance to these compounds. Thus, entomopathogenic nematodes (EPNs) are an alternative method for the control of economically important arthropods. The nematodes of genus Heterorhabditis are used in the control of arthropods, including dipterans, around the world (Dolinski et al., 2012; Aatif et al., 2019; Bream et al., 2018; Mahmoud et al., 2007), in Brazil there are studies that show the efficiency of these EPNs in the control of S. calcitrans (Leal et al., 2017; Monteiro et al., 2016).

The objectives of the present study was to evaluate the efficacy of Heterorhabditis bacteriophora (HP88) (Nematoda: Heterorhabditidae) and H. baujardi (LPP7) (Nematoda: Heterorhabditidae) infection on S. calcitrans larvae in different periods of exposure; and evaluate the efficacy of H. bacteriophora HP88 and H. baujardi LPP7, which were isolated from larvae of $S$. calcitrans on third instar larvae of the stable fly and also to verify if $S$. calcitrans larvae would be efficient for nematodes multiplication.

\section{Material and Methods}

The S. calcitrans colony was used in this study bred entirely on a bench in a laboratory environment $\left(27 \pm 1^{\circ} \mathrm{C}\right.$ and $70-80 \%$ relative humidity- $\mathrm{RH})$, the larval development diet consisted of crushed sugarcane ( $330 \mathrm{~g})$, wheat bran (125 g), meat meal $(40 \mathrm{~g})$, sodium bicarbonate $(5 \mathrm{~g})$ and distilled water $(125 \mathrm{~mL})$, using an adapted version of the method described by Moura (2015).The EPNs colony was raised using the method described by Lindegren et al. (1993), its maintenance and multiplication was done through in vivo multiplication in Galleria mellonella (Lepidoptera: Pyralidae). The infectious juveniles (IJs) were stored in an air-conditioned chamber of type B.O.D (Eletrolab ${ }^{\circledR}$, model EL 202/4) at $16 \pm 1^{\circ} \mathrm{C}$ and $70-80 \% \mathrm{RH}$ in a $40 \mathrm{~mL}$ cell culture flask for less than 7 days. The lJs were counted in twelve $10 \mu \mathrm{L}$ aliquots taken from an aqueous suspension of EPNs. After counting the IJs in the 12 aliquots, the largest and smallest number of EPNs/aliquot were discarded, and the average number of IJs in the remaining 10 aliquots was calculated. Based on this calculation, the concentration of suspensions was adjusted to IJs/mL (Taylor et al., 1998).

\section{Bioassay 1}

\section{Infection of S. calcitrans larvae by EPNs in different exposure times}

Groups of ten $3^{\text {rd }}$ third instar larvae of the fly were placed in Petri dishes $(9 \mathrm{~cm}$ in diameter) containing filter paper. Using an adapted version of the method described by Taylor et al. (1998), $200 \mathrm{IJs} / \mathrm{larva}$ were added to each Petri dish containing the $S$. calcitrans larvae. The dishes were then sealed with plastic film to prevent the S. calcitrans larvae from escaping and to prevent moisture loss. Two species of EPNs were used: $H$. bacteriophora HP88 and H. baujardi LPP7. After the exposure of S. calcitrans larvae to EPNs, the larvae were divided into groups according to the length of exposure of $2,4,6,12,24$ and 48 hours. At the end of each exposure time, the larvae were removed from the Petri dishes and deposited in plastic containers $(7.5 \times 7.5 \times 4 \mathrm{~cm})$ containing a diet for larval development, without the presence of EPNs, where they were observed until they died or formed pupae and eventually emerged as adults. The volume of water used in the control group was $4 \mathrm{~mL}$, which was the same as 
that used in the treated groups, but without EPNs. The experiment was conducted with six replicates for each group and was observed for 14 days.

After the larvae died, they were placed in traps adapted from White (1927) in order to confirm infection by EPNs by observing the presence of adult nematodes (Figure 1) inside the fly larva. This provided proof that the cycle was continuous inside the dead larvae of S. calcitrans, showing that IJs developed from the larval phase to adulthood, and that the EPNs were the cause of their death.

The design used was completely randomized, with six replications. The treatments were arranged in a $2 \times 6+1$ factorial scheme, with two nematode species (H. bacteriophora HP88 and H. baujardi LPP7), six exposure times $(2,4$, $6,12,24$ and 48h) and a control, without the presence of nematodes. A statistical analysis was performed using the factorial method with an additional control. When significant $(p<0.05)$, the interaction of 'nematodes vs. exposure time' was evaluated by breaking down the levels of each factor using the Tukey test. Dunnett's test at a probability of $5 \%$ was used to compare the control group to the other treatments, using SISVAR 5.1 software (Ferreira, 2011). The nematode $H$. bacteriophora HP88, for causing the highest mortality rates, was submitted to the test of Probit for the determination of the Lethal Time 50 (LT50) through the XLStat 7.5.2. Program, module XLstat-Dose 3.

\section{Bioassay II}

\section{Reinfection of S. calcitrans larvae by EPNs}

The nematodes used in this bioassay were recovered in White traps (White, 1927) containing S. calcitrans larvae killed due to the action of EPNs and from Bioassay I. After collection, the EPNs were stored in $40 \mathrm{~mL}$ cell culture flasks,

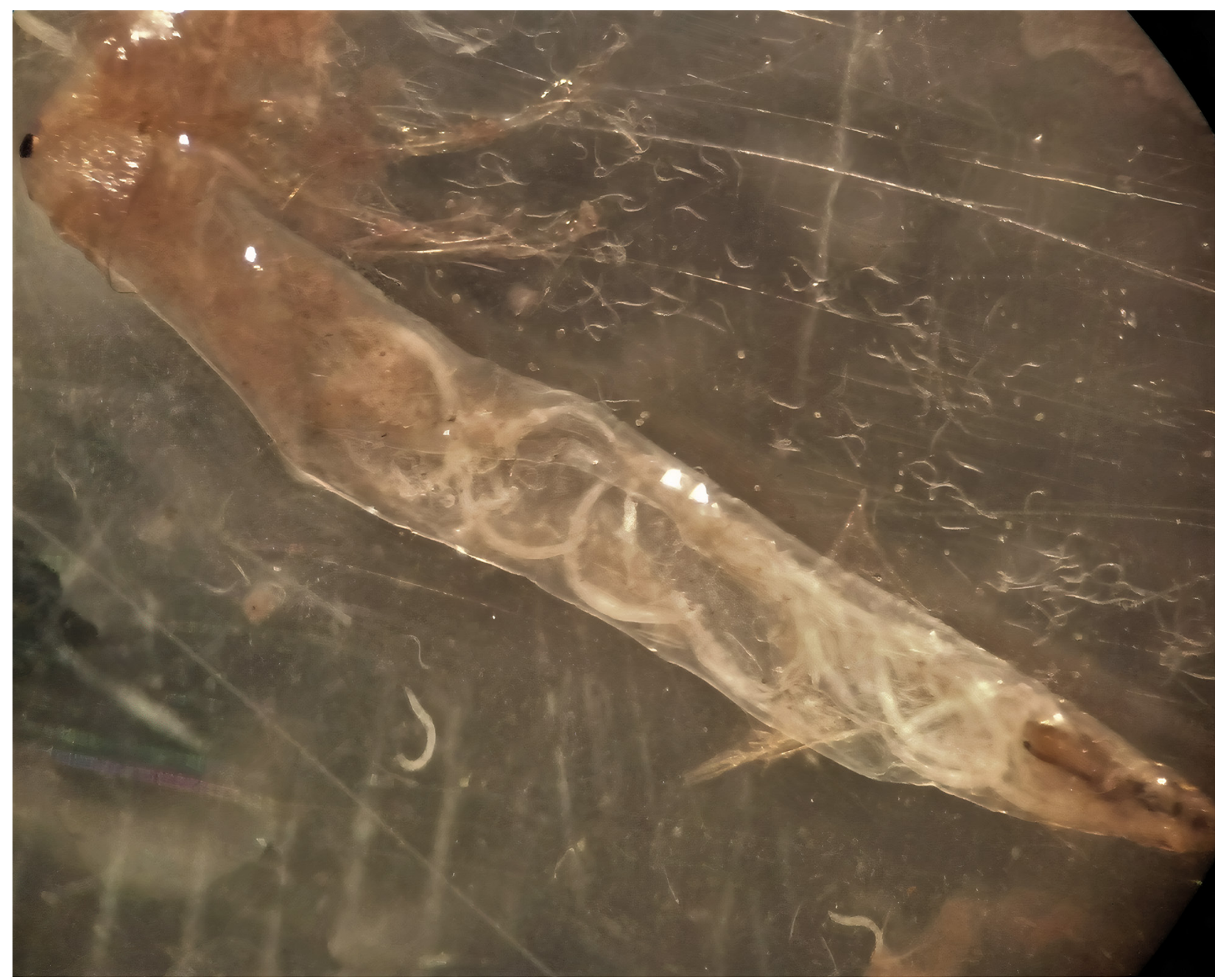

Figure 1. Infection by entomopathogenic nematodes, confirmed by the presence of adult nematodes inside stable fly larvae. 
$20 \mathrm{~mL}$ of the solution containing EPNs was collected from de White traps. A completely randomized design was used, with treatments (control, H. bacteriophora HP88 and H. baujardi LPP7) submitted to 6 replications.

Groups of $103^{\text {rd }}$ instar larvae were placed on filter paper in Petri dishes, there was no larval development diet. Then, $200 \mathrm{IJs} /$ larva were added to the dishes containing the S. calcitrans larvae. The dishes were sealed with plastic film and were monitored until the larvae died or formed pupae and eventually emerged as adults (seven days). The EPNs were in contact with the fly larvae throughout the bioassay. Each Petri dish contained $4 \mathrm{~mL}$ of water, but that of the control group contained no EPNs.

The normality of the data was determined by the Shapiro-Wilk test. The data were then subjected to an analysis of variance (ANOVA), which revealed a significant effect of the treatments, as well as to the Tukey test $(P \leq 0.05)$. Both tests were performed using SISVAR 5.1 software (Ferreira, 2011).

\section{Results and Discussion}

\section{Infection of Stomoxys calcitrans larvae by EPNs in different periods of exposure}

An analysis of the data indicated that the effect of the EPNs varied significantly as a function of exposure times. A comparison of the two nematodes (H. bacteriophora HP88 and H. baujardi LPP7) in each period of exposure revealed that the effect of the nematodes did not differ statistically from each other in the first three exposure times $(2,4$ and 6 h). However, after 12 h of exposure, H. bacteriophora HP88 caused higher mortality than H. baujardi LPP7, with larvae mortality rates of $51.7 \%, 83.3 \%$ and $91.7 \%$, respectively (Table 1). An evaluation of the periods of exposure to each nematode showed little variation in larval mortality rates caused by $H$. baujardi LPP7, with differences observed only between exposure times of 4, 24 and 48 hours compared to 12 hours. As for the effect of $H$. bacteriophora HP88, the two longest exposure times ( 24 and $48 \mathrm{~h}$ ) were significantly more effective than the others, although they did not differ statistically (Table 1). A comparison of the treatments and the control group, indicated that the following treatments were the most effective: H. baujardi LPP7 with exposure times of 24 and 48 hours, and $H$. bacteriophora HP88 with exposure times of 4, 12, 24 and 48 hours (Table 1). Therefore, the longer the exposure time of the stable fly larvae to the EPN H. bacteriophora HP88 the higher the larval mortality rate. Conversely, in the case of $H$. baujardi LPP7, the activity of this EPN against stable fly larvae remained practically constant, even after the longest period of exposure. H. bacteriophora HP88 presented LT50 of 8.32 hours. H. baujardi LPP7 had a low mortality rate, so the LT50 was not calculated for this nematode.

Studies involving exposure/infection times of arthropod pests by EPNs are still scanty in the literature. Mahmoud et al. (2007) used Steinernema feltiae N33 (Nematoda: Steinernematidae) to control third-instar larvae of S. calcitrans, which they exposed to EPN infecting juveniles for 24 and 48 hours. The authors reported a mortality rate of $16.6 \%$ after 24 hours and of $25 \%$ after 48 hours of exposure to a concentration of 200 EPNs/larva. These mortality rates are lower than those found in the present study, caused for both $\mathrm{H}$. bacteriophora HP88 (83.3\% after 24 hours and $91.7 \%$ after 48 hours) and H. baujardi LPP7 (35\% after 24 and 48 hours of exposure). Apparently, the strains used in this study are more virulent than S. feltiae N33 in the control of stable fly larvae, because both caused higher mortality rates than those reported by Mahmoud et al. (2007). This is particularly true of the mortality rates caused by the EPN H. bacteriophora HP88, which were considerably higher when compared to the aforementioned

Table 1. Mean mortality rate of Stomoxys calcitrans larvae upon exposure to entomopathogenic nematodes Heterorhabditis bacteriophora HP88 and Heterorhabditis baujardi LPP7 for different periods of time.

\begin{tabular}{|c|c|c|c|c|c|c|}
\hline \multirow{2}{*}{ Nematodes } & \multicolumn{6}{|c|}{ Exposure time (hours) } \\
\hline & 2 & 4 & 6 & 12 & 24 & 48 \\
\hline HP88 & $23.3 \mathrm{Ac}$ & $35.0 \mathrm{Abc}^{*}$ & 18.3 Ac & $51.7 \mathrm{Ab}^{*}$ & 83.3 Aa* & 91.7 Aa* \\
\hline LPP7 & 23.3 Aab & $30.0 \mathrm{Aa}$ & $20.0 \mathrm{Aab}$ & $9.3 \mathrm{Bb}$ & $35.0 \mathrm{Ba}^{*}$ & $35.0 \mathrm{Ba}^{*}$ \\
\hline Control & 18.86 & & & & & \\
\hline
\end{tabular}

Means followed by the same letter (uppercase in columns and lowercase in rows) do not differ from each other according to Tukey's test. *Means differ from the control group according to Dunnett's test $(p<0.05)$. 
study. It should be noted that Mahmoud et al. (2007) recorded the mortality rates pointwise after 24 and 48 hours of exposure of the fly larvae to EPN. Conversely, in this study, after the various periods of exposure, the fly larvae were removed from the environment with EPNs and monitored for 14 days. This two-week period may have resulted in the better results obtained in this study, since it would correspond more accurately to what happens in the environment. Moreover, EPNs of the genus Heterorhabditis have a chitinous tooth (Kaya \& Gaugler, 1993), which assists in the infection process, while nematodes of the genus Steinernema are devoid of this structure.

Leal et al. (2017) made a laboratory evaluation of the mortality rate caused by H. bacteriophora HP88 and H. baujardi LPP7 in third instar larvae of S. calcitrans. Their evaluation covered a period of 10 days, which is five times longer than the longest time used in this study (48 hours - two days). The aforementioned authors reported that a concentration of 200 infective juveniles of $H$. bacteriophora HP88 per S. calcitrans larva caused a mortality rate of $96.7 \%$ of the fly larvae, while in the present study, the mortality rate caused by $\mathrm{H}$. bacteriophora HP88 at the same concentration was 91.7\%. In addition, Leal et al. (2017) reported that $H$. baujardi LPP7 caused a larval mortality rate of $93.3 \%$, unlike in this study, in which the highest mortality rate caused by $H$. baujardi LPP7 was $35 \%$. Despite the difference in periods of exposure in the two studies, H. bacteriophora HP88 resulted a mortality rate of more than $90 \%$ in both studies. Therefore, it can be stated that this EPN is highly virulent against stable fly larvae, because even though the exposure time in the present study was considerably shorter than that used by Leal et al. (2017), H. bacteriophora HP88 was able to cause a larval mortality rate close to that reported by the aforementioned authors. However, H. baujardi LPP7 did not present same behavior, since Leal et al. (2017) reported a mortality rate of $93.3 \%$ in 10 days of exposure, while the mortality rate in the present study after two days of exposure to $H$. baujardi LPP7 was only 35\%. This indicates that the EPN H. baujardi LPP7 needs more time than H. bacteriophora HP88 in contact with fly larvae to reach its peak mortality rate, since only two days of exposure of fly larvae to this EPN did not suffice to cause a mortality rate above $90 \%$.

To control the fruit fly Ceratitis capitate (Diptera: Tephritidae), Minas (2008) exposed its larvae for 2 and 24 hours to the EPN H. baujardi LPP7, and reported mortality rates of 46.7 and $88.3 \%$, respectively. These mortality rates are higher than those recorded in the present study after 2 (23.3\%) and 24 (35.0\%) hours of exposure of S. calcitrans larvae to $H$. baujardi LPP7. This indicates that C. capitata may be more susceptible to the action of EPN H. baujardi LPP7 than S. calcitrans, since just 2 hours of exposure of $C$. capitata resulted in a higher mortality rate than that observed after 24 hours of exposure of S. calcitrans in this study. Minas (2008) used a concentration of $70 \mathrm{lJs} / \mathrm{larva}$, which is less than half the concentration used in present work ( $200 \mathrm{lJs} / \mathrm{larva}$ ). Therefore, even at a lower concentration, H. baujardi LPP7 is more pathogenic to the fruit fly C. capitata than to the stable fly S. calcitrans, since the third instar larvae of the fruit fly and the stable fly are similar in size. Hence, this factor should not have been the cause of the higher mortality rate of $C$. capitata, which may, instead, be attributed to the immune system of S. calcitrans. In fact, Boulanger et al. (2002) identified peptides with antimicrobial properties inside the stable fly, and these peptides probably interfered in the action of bacteria released by the EPN on the host hemocele. This information matches the findings of Moraes et al. (2015), who also observed antimicrobial peptides inhibiting the action of Beauveria bassiana (Bals.) Vuill on immature stages of the stable fly. Aatif et al. (2019) used EPNs to control third instar larvae of Bactrocera dorsalis (Diptera: Tephritidae). The authors reported a mortality rate of $69.42 \%$ when the larvae were exposed to H. bacteriophora HP88 for 72 hours. In this study, when stable fly larvae were exposed to the EPN H. bacteriophora HP88 for 48 hours, the mortality rate was $91.7 \%$, indicating that even in just half that exposure time, S. calcitrans appears to be more sensitive than $B$. dorsalis to the action of this EPN. According to Aatif et al. (2019), the mortality rate of $B$. dorsalis larvae after 72 hours of exposure to $H$. indica was similar to that found in the present study with stable fly larvae exposed for 48 hours to the EPN H. baujardi LPP7. In other words, the mortality rate of B. dorsalis was $37.15 \%$ and that of $S$. calcitrans was $35 \%$, indicating that, like the stable fly, $B$. dorsalis appears to be more susceptible to the action of $H$. bacteriophora HP88 than to that of $H$. indica and H. baujardi LPP7. It should be noted that Aatif et al. (2019) used a concentration of $100 \mathrm{IJs} / \mathrm{larva}$, half of that used in the present work (200 IJs/larva). This may have contributed to the differences in mortality rates of $B$. dorsalis and S. calcitrans attacked by $\mathrm{H}$. bacteriophora HP88. However, comparing the mortality rates caused to the two dipteran species by H. baujardi LPP7 and H. indica, this factor did not have a significant impact, since their mortality rates were similar.

Carvalho et al. (2010), who evaluated different periods of exposure of ingurgitated females of Rhipicephalus microplus (Acari: Ixodidae) to the EPN Steinernema glaseri CCA strain (Nematoda: Steinernematidae), reported that treatments of $2,6,12,24$ and 48 h resulted mortality rates of $66 \%, 78 \%$ and $83.7 \%, 99.9 \%$, and $99 \%$, respectively. These rates are higher than those of this study with the stable fly, where the highest mortality rate was $91.7 \%(H$. bacteriophora HP88-48h). The differences between hosts and EPNs should be taken into account, because although 
both hosts are arthropods, they belong to different classes, which indicates that ticks may be more susceptible than flies to the action of EPNs. However, this comparison should be made carefully, since the EPN (S. glaseri CCA) used in the aforementioned study belongs to another genus, different from the genus used in this study work, in which the two EPNs were of the genus Heterorhabditis. Another important fact is that Carvalho et al. (2010) used a concentration of $1000 \mathrm{lJs}$ per ingurgitated female, while the concentration used in the present study was five times lower (200 IJs/fly larva). In fact, the superior results reported the aforementioned authors can be attributed to this higher concentration. Monteiro et al. (2012) evaluated different periods of exposure of R. microplus engorged females to the EPN H. bacteriophora HP88 (300 IJs/female), and reported that $6 \mathrm{~h}$ and $12 \mathrm{~h}$ of exposure resulted in mortality rates of $12.24 \%$ and $32.62 \%$, respectively. Their results are lower than those of the present study with H. bacteriophora HP88, in which the larval mortality rate in $6 \mathrm{~h}$ of exposure was $18.3 \%$ and in $12 \mathrm{~h}$ it was $51.7 \%$. However, Monteiro et al. (2012) reported that mortality rates were $82.54 \%$ after 24 hours of exposure, and $100 \%$ after 48 hours of exposure. Those mortality rates are higher than the rates achieved in the present study, where the highest mortality rate was $91.7 \%$ (48h), indicating that, apparently, after longer periods of exposure to EPNs, R. microplus engorged females are more affected than stable fly larvae.

The periods of exposure tested in this study were necessary to clarify how much time was required for the entomopathogenic nematodes to successfully infect and then kill S. calcitrans larvae. This knowledge is important because, if these EPNs are used in an environment where the target arthropod is present, the nematodes are subjected to abiotic factors such as ultraviolet radiation, temperature and humidity, bearing in mind that these organisms undergo loss of viability at relative humidity levels below $60 \%$ (Baur et al., 1995). Therefore, the faster the nematodes enter the host the lower their risk of exposure to these factors, since the infectivity of $\mathrm{H}$. bacteriophora HP88 (which proved more virulent in this study) decreases at temperatures above $40.1^{\circ} \mathrm{C}$. EPNs do not have a well-adapted relationship to their hosts, so the stable fly and other arthropods have no short-term resistance to them (Kaya \& Gaugler, 1993).

Greater attention should focus on studies of EPNs as a form of control of arthropods of veterinary importance, because although the mortality rates they cause are not higher than those required for registration with the Ministry of Agriculture, Livestock and Food Supply (MAPA), unlike chemical pesticides, they are quite virulent against arthropods. Moreover, they are mobile and can be produced at low cost, they survive storage for long periods, they are compatible with most chemical pesticides and they can be applied via irrigation or water spraying (Koppenhöfer \& Grewal, 2005). All these factors make EPNs agents with a potential for use in the control of S. calcitrans and other arthropod pests that have a developmental stage in soil (Kaya \& Gaugler, 1993). EPNs can be used separately or in combination with chemical pesticides (integrated control), since they will also act on populations of resistant insects, aiming to reduce losses and increase Brazil's agricultural productivity.

\section{Reinfection of Stomoxys calcitrans larvae by EPNs}

In terms of the variable of mortality, the EPNs used here differed statistically, showing mortality rates of $15 \%$ in the control group, $25 \%$ by H. baujardi LPP7 and 35\% by H. bacteriophora HP88. As for the variable of emergence rate, the treated groups and the control group showed no significant difference, and the overall average emergence rate of the groups was $70.54 \%$. To determine which treatment achieved the highest mortality rate, the Tukey test $(\mathrm{p} \leq 0.05$ ) was performed (Table 2 ). This test indicated that the mortality rate caused by H. bacteriophora HP88 (35\%) was statistically higher than that of the control group (15\%), but did not differ statistically from that caused by $H$. baujardi LPP7 (25\%), since a comparison of the mortality rate of $H$. baujardi LPP7 with that of the control group indicated that they were statistically the same. The fact that EPNs reproduce in $S$. calcitrans larvae could help maintain IJs in the environment, to control future generations of the stable fly.

Monteiro et al. (2016) used H. bacteriophora HP88 for the control of S. calcitrans larvae developing in filter cake. The EPNs used by these authors were bred in G. mellonella and they reported a mortality rate of $83.3 \%$ using 200 IJs/larva. Conversely, the larval mortality rate in the present study was only $35 \%$ when using the same concentration of nematodes. The mortality rate reached in the present study is close to that achieved by Monteiro et al. (2016) with a concentration of $25 \mathrm{IJs} / \mathrm{larva}(38.33 \%)$, indicating that when bred in G. mellonella, even the lowest EPN/larva concentrations used by those authors achieved higher than mortality rates than in this study with $\mathrm{H}$. bacteriophora HP88 bred in S. calcitrans. The rate achieved by Monteiro et al. (2016) in the presence of filter cake is remarkable, given that filter cake is rich in organic matter, which decreases the oxygen levels for EPNs and might have had a negative effect on their action. 
Table 2. Mean Stomoxys calcitrans larvae mortality rate and emergence rate in response to the action of EPNs Heterorhabditis bacteriophora HP88 and H. baujardi LPP7.

\begin{tabular}{ccc}
\hline Treatments & Mortality Rate & Emergence Rate \\
\hline Control & $15.0 \mathrm{~b}$ & $73.84 \mathrm{a}$ \\
LPP7 & $25.0 \mathrm{ab}$ & $66.74 \mathrm{a}$ \\
HP88 & $35.0 \mathrm{a}$ & $71.06 \mathrm{a}$ \\
\hline
\end{tabular}

Means followed by the same letter in the columns do not differ according to Tukey's test $(p \leq 0.05)$.

Mendes et al. (2016) reported emergence rates ranging from 74.5 to $84 \%$ using stable fly larvae bred on a diet of sugarcane, crude ash and vinasse. These values do not differ much from the emergence rate found in this work using EPNs to control S. calcitrans. Therefore, the EPNs may not have had a negative effect on the adult stable fly emergence rate, and its virulence may have been attenuated after being isolated from stable fly larvae. This decrease in entomopathogenic nematode virulence may be attributed to the action of antimicrobial peptides found in the intestine of stable fly larvae (Moraes et al., 2015), which may have affected the bacterial symbionts that EPNs harbor when they were still inside the $S$. calcitrans larvae from which they were isolated.

\section{Conclusions}

It was concluded that the EPNs tested proved effective in the control of third instar larvae of the stable fly and the longest exposure times presented the highest larval mortality. The EPN H. bacteriophora HP88 is the most recommended for control of the stable fly, presenting LT50 of 8.32 hours (Bioassay I). The EPNs isolated from $S$. calcitrans (Bioassay II) were not virulent for the fly larvae.

\section{Acknowledgements}

This work was supported by Conselho Nacional de Desenvolvimento Científico e Técnológico (CNPq) and by the Programa de Pós Graduação em Ciências Veterinárias da Universidade Federal Rural do Rio de Janeiro (PPGCVUFRRJ).

\section{References}

Aatif HM, Hanif MS, Ferhan M, Raheel M, Shakeel Q, Ashraf W, et al. Assessment of the entomopathogenic nematodes against maggots and pupae of the oriental fruit fly, Bactrocera dorsalis (Hendel) (Diptera: Tephritidae), under laboratory conditions. Egypt J Biol Pest Control 2019; 29(1): 51. http://dx.doi.org/10.1186/s41938-019-0154-4.

Barros TM, Rodrigues VD, Cançado PHD, Domingues LN. Resistance of the stable fly, Stomoxys calcitrans (Diptera: Muscidae), to cypermethrin in outbreaks areas in Midwestern Brazil. Rev Bras Parasitol Vet 2019; 28(4): 802-806. http://dx.doi.org/10.1590/ s1984-29612019089. PMid:31691737.

Baur ME, Kaya HK, Thurston GS. Factors affecting entomopathogenic nematode infection of Plutella xylostella on a leaf surface. Entomol Exp App/ 1995; 77(3): 239-250. http://dx.doi.org/10.1111/j.1570-7458.1995.tb02321.x.

Bittencourt AJ. Avaliação de surtos e medidas de controle ambiental de Stomoxys calcitrans (Diptera: Muscidae) na Região Sudeste do Brasil. Rev Bras Med Vet 2012; 34(Suppl. 1): 73-82.

Boulanger N, Munks RJL, Hamilton JV, Vovelle F, Brun R, Lehane MJ, et al. Epithelial Innate Immunity - A novel antimicrobial peptide with antiparasitic activity in the blood-sucking insect Stomoxys calcitrans. J Biol Chem 2002; 277(51): 49921-49926. http:// dx.doi.org/10.1074/jbc.M206296200. PMid:12372834.

Bream A, Fouda MA, Shehata I, Ragab S. Evaluation of four entomopathogenic nematodes as biological control agents against the housefly, Musca domestica L. (Diptera: muscidae). Egypt Acad Biolog Sci 2018; 11(1): 79-89. http://dx.doi.org/10.21608/ eajb.2018.11982.

Carvalho LB, Furlong J, Prata MCA, Reis ES, Batista ESP, Faza AP, et al. Evaluation in vitro of the infection times of engorged females of Rhipicephalus (Boophilus) microplus by the entomopathogenic nematode Steinernema glaseri CCA strain. Cienc Rural 2010; 40(4): 939-943. http://dx.doi.org/10.1590/S0103-84782010000400030. 
Dolinski C, Choo HY, Duncan LW. Grower acceptance of entomopathogenic nematodes: case studies on three continents. J Nematol 2012; 44(2): 226-235. PMid:23482423.

Dominghetti TFS, Barros ATM, Soares CO, Cançado PH. Stomoxys calcitrans (Diptera: Muscidae) outbreaks: current situation and future outlook with emphasis on Brazil. Rev Bras Parasito/ Vet 2015; 24(4): 387-395. http://dx.doi.org/10.1590/S1984-29612015079. PMid:26689177.

Ferreira DF. Sisvar: a computer statistical analysis system. Cienc Agrotec 2011; 35(6): 1039-1042. http://dx.doi.org/10.1590/ S1413-70542011000600001.

Grisi L, Leite RC, Martins JR, Barros ATM, Andreotti R, Cançado PHD, et al. Reassessment of the potential economic impact of cattle parasites in Brazil. Rev Bras Parasitol Vet 2014; 23(2): 150-156. http://dx.doi.org/10.1590/S1984-29612014042. PMid:25054492.

Kaya HK, Gaugler R. Entomopathogenic nematodes. Annu Rev Entomol 1993; 38(1): 181-206. http://dx.doi.org/10.1146/annurev. en.38.010193.001145.

Koppenhöfer AM, Grewal PS. Compatibility and interactions with agrochemicals and other biocontrol agents. In: Grewal PS, Ehlers RU, Shapiro-Ilan DI, editors. Nematodes as biological control agents. Wallingford: CAB International; 2005. p. 363-381. http:// dx.doi.org/10.1079/9780851990170.0363.

Leal LCSR, Monteiro CMO, Mendonça AE, Bittencourt VREP, Bittencourt AJ. Potential of entomopathogenic nematodes of the genus Heterorhabditis for the control of Stomoxys calcitrans (Diptera: muscidae). Rev Bras Parasitol Vet 2017; 26(4): 451-456. http:// dx.doi.org/10.1590/s1984-29612017065. PMid:29160358

Lindegren JE, Valero KA, Mackey BE. Simple in vivo production and storage methods for Steinernema carpocapsae infective juveniles. J Nematol 1993; 25(2): 193-197. PMid:19279758.

Mahmoud MF, Mandour NS, Pomazkov IY. Efficacy of the entomopathogenic nematode Steinernema feltiae cross n 33 against larvae and pupae of four fly species in the laboratory. Nematol Mediterr 2007; 35(2): 221-226.

Mendes COF, Silva AC, Leal LCSR, Barbosa CG, Bittencourt AJ. Biologia de Stomoxys calcitrans (Diptera: Muscidae) em subprodutos da indústria sucroalcooleira. Rev Bras Med Vet [online] 2016; 38(Suppl. 3): 31-36 [cited 2021 March 8]. Available from: http://rbmv. org/index.php/BJVM/article/view/311

Minas RS. Potencial dos nematóides entomopatogênicos como agentes de controle biológico da mosca-do-Mediterrâneo Ceratitis capitata (Wied.) (Diptera: Tephritidae) [dissertação]. Rio de Janeiro: Universidade Estadual do Norte Fluminense Darcy Ribeiro; 2008.

Monteiro CMO, Prata MCA, Faza A, Batista ESP, Dolinski C, Furlong J. Heterorhabditis bacteriophora (Rhabditida: Heterorhabditidae) HP88 for biological control of Rhipicephalus microplus (Acari: Ixodidae): the effect of different exposure times of engorged females to the nematodes. Vet Parasito/ 2012; 185(2-4): 364-367. http://dx.doi.org/10.1016/j.vetpar.2011.10.007. PMid:22093907.

Monteiro AC So, Mendes COF, Leal LCSR, Bittencourt AJ. Virulência de Heterorhabditis bacteriophora cepa HP88 (Rhabditida: Heterorhabtidae) sobre larvas de Stomoxys calcitrans (Díptera: Muscidae) em dieta de torta de filtro. Rev Bras Med Vet 2016; 38(Suppl. 3): 9-13.

Moraes APR, Salles CMC, Bittencourt VREP, Bittencourt AJ. Antimicrobial activity of Stomoxys calcitrans against Beauveria bassiana sensu lato isolates. Rev Bras Parasitol Vet 2015; 24(3): 331-339. http://dx.doi.org/10.1590/S1984-29612015064. PMid:26444064.

Moura FSV. Desenvolvimento de substratos para criação de mosca-dos-estábulos Stomoxys calcitrans (Diptera: Muscidae) em laboratório [dissertação]. Campo Grande: Universidade Federal de Mato Grosso do Sul; 2015.

Taylor DB, Moon RD, Mark DR. Economic impact of stable flies (Diptera: Muscidae) on dairy and beef cattle production. $J$ Med Entomol 2012; 49(1): 198-209. http://dx.doi.org/10.1603/ME10050. PMid:22308789.

Taylor DB, Szalanski AL, Adams BJ, Peterson RD 2nd. Susceptibility of house fly (Diptera: Muscidae) larvae to entomopathogenic nematodes (Rhabditida: Heterorhabditidae, Steinernematidae). Environ Entomo/ 1998; 27(6): 1514-1519. http://dx.doi.org/10.1093/ ee/27.6.1514.

White GF. A method for obtaining infective nematode larvae from cultures. Science 1927; 66(1709): 302-303. http://dx.doi. org/10.1126/science.66.1709.302-a. PMid:17749713. 